\title{
Melanoma of the Iris pTX TNM Finding v7
}

National Cancer Institute

\section{Source}

National Cancer Institute. Melanoma of the Iris PTX TNM Finding v7. NCI Thesaurus.

Code C88670.

Melanoma of the iris in which the primary tumor cannot be assessed. (from AJCC 7th Ed.) 